\title{
Multinuclear Variable-temperature Nuclear Magnetic Resonance Study of Rhodium Carbonyl Clusters containing Encapsulated Heteroatoms: Ligand and Metal Polyhedral Rearrangements
}

\author{
Brian T. Heaton, * Luisella Strona, and Roberto Della Pergola \\ Chemical Laboratory, University of Kent, Canterbury CT2 $7 \mathrm{NH}$ \\ José L. Vidal * and Richard C. Schoening \\ Union Carbide Corporation, Research and Development Department, P.O. Box 8361, South Charleston, \\ West Virginia 25304, U.S.A.
}

\begin{abstract}
Variable-temperature multinuclear n.m.r. studies $\left({ }^{13} \mathrm{C},{ }^{13} \mathrm{C}-\left\{{ }^{103} \mathrm{Rh}\right\},{ }^{13} \mathrm{C}-\left\{{ }^{31} \mathrm{P}\right\}\right.$, and $\left.{ }^{31} \mathrm{P}\right)$ are reported for $\left[R h_{9} E(C O)_{21}\right]^{2-},\left[R h_{10} E(C O)_{22}\right]^{3-}(E=P$ or $A s)$, and $\left[R h_{12} S b(C O)_{27}\right]^{3-}$. In all cases, complete fluxionality of both the carbonyl and metal polyhedra are observed at high temperatures, and at low temperatures it has been possible to obtain spectra for the $R h_{9}$ and $R h_{10}$ clusters, which are fully consistent with their solid-state structures, thus allowing a complete spectroscopic assignment; the $\mathrm{Rh}_{12}$ cluster is still fluxional in solution at $-97^{\circ} \mathrm{C}$.
\end{abstract}

A variety of high nuclearity carbonyl clusters containing interstitial heteroatoms is now known. The recent discovery of the closely related clusters $\left[R h_{9} E(C O)_{21}\right]^{2-}$ and $\left[R h_{10} E-\right.$ $\left.(\mathrm{CO})_{22}\right]^{3-}(\mathrm{E}=\mathrm{P} \text { or } \mathrm{As})^{1-3}$ enabled us to carry out variabletemperature n.m.r. measurements in order to compare their behaviour in solution and spectroscopic data. These clusters are particularly interesting since previous ${ }^{103} \mathrm{Rh}$ n.m.r. measurements on $\left[\mathrm{Rh}{ }_{9} \mathrm{P}(\mathrm{CO})_{21}\right]^{2-}$ showed that the metal skeleton is fluxional. ${ }^{4} \mathrm{We}$ also report related studies on $\left[\mathrm{Rh}_{12} \mathrm{Sb}(\mathrm{CO})_{27}\right]^{3-.5}$

\section{Experimental}

The syntheses of the anionic carbonyl clusters $\left[\mathrm{Rh}, \mathrm{E}(\mathrm{CO})_{21}\right]^{2-}$, $\left[R h_{10} E(C O)_{22}\right]^{3-}(E=P$ or $A s)$, and $\left[R_{12} \mathrm{Sb}(C O)_{27}\right]^{3-}$ were conducted following previously described procedures. ${ }^{1-3,5,6}$ All manipulations were carried out using Schlenk-tube techniques under an argon atmosphere and solvents were dried using conventional procedures and stored under argon.

The solutions for n.m.r. measurements were prepared by saturating perdeuterioacetone $\left(3 \mathrm{~cm}^{3}\right)$ with either the $\left[\mathrm{NEt}_{3^{-}}\right.$ $\left.\left(\mathrm{CH}_{2} \mathrm{Ph}\right)\right]^{+}$or $\left[\mathrm{Cs}\left\{\mathrm{Me}\left(\mathrm{OCH}_{2} \mathrm{CH}_{2}\right)_{4} \mathrm{OMe}\right\}\right]^{+}$salts of the cluster anions $(0.4-0.6 \mathrm{~g})$. The complexes were enriched by direct exchange of solutions with ${ }^{13} \mathrm{CO}$ under ambient conditions using standard vacuum-line techniques; the final enrichment was $c a .40 \%$. The ${ }^{13} \mathrm{C}$-enriched samples were transferred via syringe into an evacuated n.m.r. tube placed inside a Schlenk container under argon; the tubes were then sealed.

Carbon-13 n.m.r. spectra were recorded on either a Varian XL-100 n.m.r. spectrometer, equipped with Fourier-transform capabilities, using 12-mm sample tubes, or on a JEOL PS100 or Bruker WH360 Fourier-transform spectrometer as described previously; ${ }^{7}{ }^{13} \mathrm{C}-\left\{{ }^{103} \mathrm{Rh}\right\}$ and ${ }^{13} \mathrm{C}-\left\{{ }^{31} \mathrm{P}\right\}$ measurements were carried out as described previously. ${ }^{8,9}$ Carbon-13 chemical shifts are reported in p.p.m. from $\mathrm{SiMe}_{4},{ }^{31} \mathbf{P}$ chemical shifts in p.p.m. from external phosphoric acid, and, for $\delta\left({ }^{103} \mathrm{Rh}\right), 0$ p.p.m. $=3.16 \mathrm{MHz}$ at such a magnetic field that the protons for $\mathrm{SiMe}_{4}$ in $\mathrm{CDCl}_{3}$ solution resonate at exactly $100 \mathrm{MHz}$; high-frequency shifts are positive.

\section{Results}

The solid-state structures of $\left[\mathrm{Rh}_{9} \mathrm{E}(\mathrm{CO})_{21}\right]^{2-}$ and $\left[\mathrm{Rh}_{10} \mathrm{E}\right.$ $\left.(\mathrm{CO})_{22}\right]^{3-}$ are shown schematically in Figure 1. Each rhodium atom in both clusters is bonded to one terminal carbonyl, which has been omitted from the Figure for the sake of clarity.

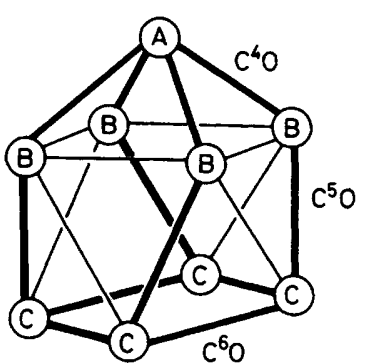

(a)

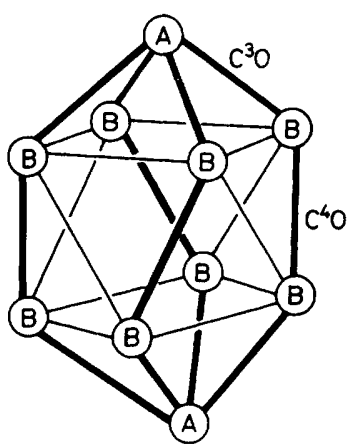

(b)
Figure 1. Schematic representation of $(a)\left[\mathrm{Rh}_{9} \mathrm{E}(\mathrm{CO})_{21}\right]^{2-}$ and $(b)$ $\left[\mathrm{Rh}_{10} \mathrm{E}(\mathrm{CO})_{22}\right]^{3-}(\mathrm{E}=\mathrm{P}$ or As) showing the minimum reorganisation of the carbonyl skeleton which occurs on going from the $R_{h}$ to the $R h_{10}$ cluster. Each rhodium in both clusters has one terminal carbonyl group $\left(\mathrm{Rh}_{\mathrm{A}}-\mathrm{C}^{1} \mathrm{O}, \mathrm{Rh}_{\mathrm{B}}-\mathrm{C}^{2} \mathrm{O}, \mathrm{Rh}_{\mathrm{C}}-\mathrm{C}^{3} \mathrm{O}\right)$ which has been omitted for clarity; bold lines indicate bridging $\mathrm{CO}$ groups

In $\left[\mathrm{Rh} \mathrm{h}_{9} \mathrm{E}(\mathrm{CO})_{21}\right]^{2-}$ there are three types of terminal carbonyls, $\mathrm{Rh}_{\mathrm{A}}-\mathrm{C}^{1} \mathrm{O}, \mathrm{Rh}_{\mathrm{B}}-\mathrm{C}^{2} \mathrm{O}$, and $\mathrm{Rh}_{\mathrm{C}}-\mathrm{C}^{3} \mathrm{O}$ in the ratio $1: 4: 4$, and for $\left[R h_{10} E(C O)_{22}\right]^{3-}$ there are two types of terminal carbonyls, $\mathrm{Rh}_{\mathrm{A}}-\mathrm{C}^{1} \mathrm{O}$ and $\mathrm{Rh}_{\mathrm{B}}-\mathrm{C}^{2} \mathrm{O}$ in the ratio $2: 8$. The edge-bridging carbonyls in $\left[R h_{9} E(C O)_{21}\right]^{2-}$ fall into three equally intense sets with $\mathrm{C}^{4} \mathrm{O}$ bridging all $\mathrm{Rh}_{\mathrm{A}}-\mathrm{R} \mathrm{h}_{\mathrm{B}}$ edges, $\mathrm{C}^{5} \mathrm{O}$ bridging alternate $R h_{B}-R h_{C}$ edges, and $C^{6} O$ bridging all $R h_{C}-R h_{C}$ edges. For $\left[\mathrm{Rh}_{10} \mathrm{E}(\mathrm{CO})_{22}\right]^{3-}$ there are two types of edgebridging carbonyls, $\mathrm{C}^{3} \mathrm{O}$ and $\mathrm{C}^{4} \mathrm{O}$ in the ratio $8: 4$ with $\mathrm{C}^{3} \mathrm{O}$ bridging all $R h_{A}-R h_{B}$ edges and $C^{4} O$ bridging alternate $\mathrm{Rh}_{\mathrm{B}}-\mathrm{R} \mathrm{h}_{\mathrm{B}}$ edges.

Inspection of Figure 1 shows that there is minimal rearrangement of the carbonyl polyhedron on going from the $\mathrm{Rh}_{9}$ to the $\mathrm{Rh}_{10}$ cluster.

$\left[\mathrm{Rh}_{10} \mathrm{E}(\mathrm{CO})_{22}\right]^{3-}(\mathrm{E}=\mathbf{P}$ or $\mathrm{As}) .-$ The low-temperature $\left(-91{ }^{\circ} \mathrm{C}\right){ }^{13} \mathrm{C}$ n.m.r. spectrum of $\left[\mathrm{Rh}_{10} \mathrm{P}(\mathrm{CO})_{22}\right]^{3-}$ in acetone is shown in Figure 2(c), together with the rhodium-decoupled [Figure 2(a) and $(b)$ ] and phosphorus-decoupled [Figure 2(d)] spectra, which allow unambiguous assignment. The undecoupled spectrum clearly shows four groups of resonances at $246.9,238.8,199.0$, and 193.9 p.p.m. with relative intensities $4: 8: 2: 8$ due to $\mathrm{C}^{4} \mathrm{O}, \mathrm{C}^{3} \mathrm{O}, \mathrm{C}^{1} \mathrm{O}$, and $\mathrm{C}^{2} \mathrm{O}$ respectively. All the resonances, except $\mathrm{C}^{4} \mathrm{O}$, show coupling to phosphorus, 

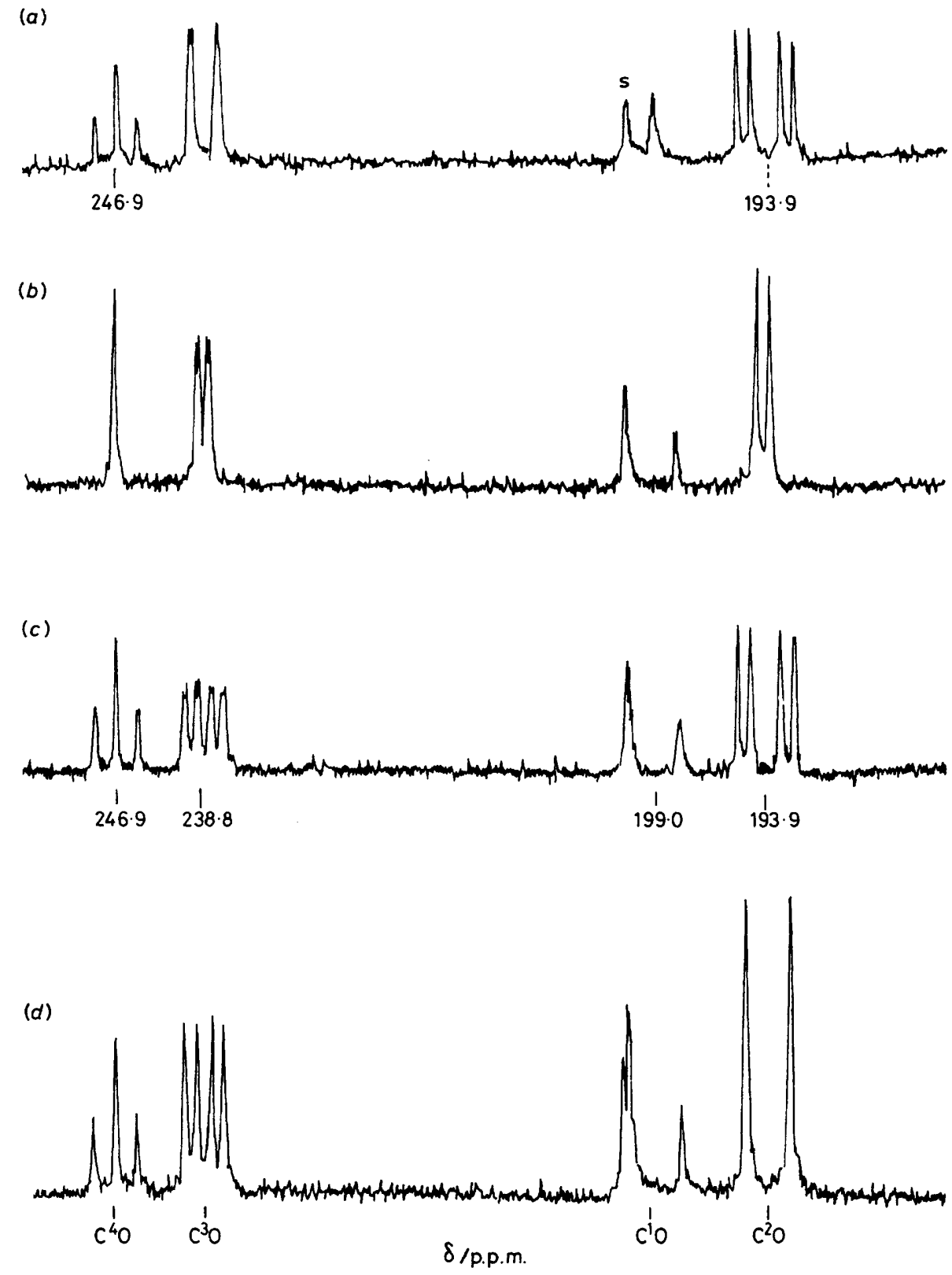

Figure 2. $25-\mathrm{MHz}{ }^{13} \mathrm{C}-\left\{{ }^{103} \mathrm{Rh}\right\}$ and ${ }^{13} \mathrm{C}-\left\{{ }^{31} \mathrm{P}\right\}$ n.m.r. spectra of $\left[\mathrm{Cs}\left\{\mathrm{Me}\left(\mathrm{OCH}_{2} \mathrm{CH}_{2}\right)_{4} \mathrm{OMe}\right\}\right]_{3}\left[\mathrm{Rh}_{10} \mathrm{P}(\mathrm{CO})_{22}\right]$ in $\left(\mathrm{CD}_{3}\right)_{2} \mathrm{CO}$ at -91 年: (a) decoupling $\mathrm{Rh}_{\mathrm{A}}\left[\Xi 3.158097 \mathrm{MHz}, \delta\left(\mathrm{Rh}_{\mathrm{A}}\right)-607\right.$ p.p.m.]; (b) decoupling $\mathrm{Rh}_{\mathrm{B}}\left[\Xi 3.155967 \mathrm{MHz}, \delta\left(\mathrm{Rh} \mathrm{B}_{\mathrm{B}}\right)-1281\right.$ p.p.m.]; (c) undecoupled; $(d)$ decoupling $\mathrm{P}[\Xi 40.496150 \mathrm{MHz}, \delta(\mathrm{P})+376.9$ p.p.m. $] . \mathrm{S}=$ solvent

which has been confirmed in the ${ }^{13} \mathrm{C}-\left\{{ }^{31} \mathrm{P}\right\}$ spectrum [Figure $2(d)] .{ }^{13} \mathrm{C}-\left\{{ }^{103} \mathrm{Rh}\right\}$ Measurements show there to be two rhodium resonances ( $\Xi 3.158097$ and $3.155967 \mathrm{MHz}$ ), which can be assigned to $\mathrm{Rh}_{\mathrm{A}}\left(-607\right.$ p.p.m.) and $\mathrm{Rh}_{\mathrm{B}}(-1281$ p.p.m.) respectively. Thus, decoupling $\mathrm{Rh}_{\mathrm{A}}$ [Figure $2(a)$ ] causes the resonance due to $\mathrm{C}^{1} \mathrm{O}$ at 199.0 p.p.m. to collapse and the resonance due to $\mathrm{C}^{3} \mathrm{O}$ at 238.8 p.p.m. to become a doublet of doublets due to residual coupling to $R h_{B}$ and to the interstitial phosphorus. Similarly, decoupling $\mathrm{Rh}_{\mathbf{B}}$ [Figure $2(b)$ ] causes the resonance due to $\mathrm{C}^{4} \mathrm{O}$ at 246.9 p.p.m. to become a singlet and the terminal carbonyl resonance due to $\mathrm{C}^{2} \mathrm{O}$ at 193.9 p.p.m. collapses to a doublet due to residual interaction with the interstitial phosphorus. These data, together with those ${ }^{10}$ for the corresponding clusters $\left[R h_{10} A s(C O)_{22}\right]^{3-}$ and $\left[R h_{10} S-\right.$ $\left.(\mathrm{CO})_{22}\right]^{2-}$ at low temperature, are summarised in Table 1 . The data for all three compounds are very similar with the different rhodium-carbon spin-spin coupling values to $\mathrm{C}^{3} \mathrm{O}$ reflecting the different values of $d\left(\mathrm{Rh}_{\mathrm{A}}-\mathrm{C}^{3} \mathrm{O}\right) 2.24 \AA$ and $d\left(\mathrm{Rh}_{\mathrm{B}}-\mathrm{C}^{3} \mathrm{O}\right) 1.92 \AA$ caused through asymmetric bridging. When considering the wide range of ${ }^{103} \mathrm{Rh}$ chemical shifts that are presently known, ${ }^{11}$ the variation for the compounds in Table 1 is not very large. It therefore seems probable that, in keeping with previous results, ${ }^{12}$ the increased charge on going from the di- to the tri-anion is mainly dissipated onto the carbonyls as reflected by the mean carbonyl chemical shift moving to lower field with increased charge on the anion $\left[\delta\left({ }^{13} \mathrm{CO}\right)_{\text {mean }}=215,220.2\right.$, and 219.4 p.p.m. for $\mathrm{E}=\mathrm{S}, \mathrm{P}$ and As respectively].

Variable-temperature ${ }^{13} \mathrm{C}$ n.m.r. spectra of $\left[\mathrm{Rh}{ }_{10} \mathrm{P}(\mathrm{CO})_{22}\right]^{3-}$ show that all the carbonyl resonances broaden simultaneously 
Table 1. N.m.r. data for $\left[\mathrm{Rh}_{10} \mathrm{E}(\mathrm{CO})_{22}\right]^{n-}(\mathrm{E}=\mathrm{P}$ or $\mathrm{As}, n=3$; $\mathrm{E}=\mathrm{S}, n=2$ ) at low temperature

\begin{tabular}{|c|c|c|c|}
\hline & \multicolumn{3}{|c|}{ E } \\
\hline & $\mathrm{P}^{a}$ & As ${ }^{b}$ & $\mathrm{~S}^{c}$ \\
\hline$\delta\left(\mathrm{C}^{\mathrm{l}} \mathrm{O}\right) /$ p.p.m. & 199.0 & 202.9 & 200.3 \\
\hline$\delta\left(\mathrm{C}^{2} \mathrm{O}\right) /$ p.p.m. & 193.9 & 194.6 & 192.5 \\
\hline$\delta\left(\mathrm{C}^{3} \mathrm{O}\right) /$ p.p.m. & 238.8 & 235.6 & 230.8 \\
\hline$\delta\left(\mathrm{C}^{4} \mathrm{O}\right) /$ p.p.m. & 246.9 & 244.8 & 236.9 \\
\hline${ }^{1} J\left(\mathrm{Rh}_{\mathrm{A}}-\mathrm{C}^{1} \mathrm{O}\right) / \mathrm{Hz}$ & 103.5 & 115.7 & 109.9 \\
\hline${ }^{1} J\left(\mathrm{Rh}_{\mathrm{B}}-\mathrm{C}^{2} \mathrm{O}\right) / \mathrm{Hz}$ & 90.3 & 93.6 & 94.6 \\
\hline${ }^{1} J\left(\mathrm{Rh}_{\mathrm{A}}-\mathrm{C}^{3} \mathrm{O}\right) / \mathrm{Hz}$ & 25.4 & 26.1 & 27.5 \\
\hline${ }^{1} J\left(\mathrm{Rh}_{\mathrm{B}}-\mathrm{C}^{3} \mathrm{O}\right) / \mathrm{Hz}$ & 53.7 & 55.6 & 55.0 \\
\hline${ }^{1} J\left(\mathrm{Rh}_{\mathrm{B}}-\mathrm{C}^{4} \mathrm{O}\right) / \mathrm{Hz}$ & 43.9 & 43.2 & 42.7 \\
\hline$\delta\left(\mathrm{Rh}_{\mathbf{A}}\right) /$ p.p.m. & -607 & -495 & $-755^{d}$ \\
\hline$\delta\left(\mathrm{Rh}_{\mathrm{B}}\right) /$ p.p.m. & -1281 & -1220 & $-1169^{d}$ \\
\hline$\delta(\mathrm{P}) / \mathrm{p} \cdot \mathrm{p} \cdot \mathrm{m}$ & $+376.9^{e}$ & & \\
\hline${ }^{2} J\left(\mathrm{Rh}_{\mathrm{A}}-\mathrm{P}\right) / \mathrm{Hz}$ & $56^{e}$ & & \\
\hline${ }^{1} J\left(\mathrm{Rh}_{\mathrm{B}}-\mathrm{P}\right) / \mathrm{Hz}$ & $21^{e}$ & & \\
\hline${ }^{2} J\left(\mathrm{P}-\mathrm{C}^{1} \mathrm{O}\right) / \mathrm{Hz}$ & 5.9 & & \\
\hline${ }^{2} J\left(\mathrm{P}-\mathrm{C}^{2} \mathrm{O}\right) / \mathrm{Hz}$ & 26.9 & & \\
\hline${ }^{2} J\left(\mathrm{P}-\mathrm{C}^{3} \mathrm{O}\right) / \mathrm{Hz}$ & 5.9 & & \\
\hline
\end{tabular}

${ }^{a}$ In $\left(\mathrm{CD}_{3}\right)_{2} \mathrm{CO}$. At $-91{ }^{\circ} \mathrm{C}$ except where indicated. ${ }^{b}$ In $\left(\mathrm{CD}_{3}\right)_{2} \mathrm{CO}$ at $-95{ }^{\circ} \mathrm{C}$. ${ }^{c}$ In $\left[{ }^{2} \mathrm{H}_{8}\right]$ tetrahydrofuran. At $-82{ }^{\circ} \mathrm{C}$ except where indicated. ${ }^{d}$ At $-70^{\circ} \mathrm{C} .{ }^{e} \mathrm{At}-80^{\circ} \mathrm{C}$.

due to the onset of a concerted scrambling of all the carbonyl ligands rather than any localised fluxional process. In sulpholane (tetrahydrothiophene 1,1 -dioxide) at $+100{ }^{\circ} \mathrm{C}$ there is just one resonance at 221.3 p.p.m., which agrees well with the weighted average of the resonances in the spectrum in acetone solution at $-90{ }^{\circ} \mathrm{C}$ (see above). However, this resonance is not a well resolved multiplet, as found for the corresponding $\left[\mathrm{Rh}_{10} \mathrm{As}(\mathrm{CO})_{22}\right]^{3-}$ (see below), but it is not possible to go to higher temperatures in order to produce the fastexchange limiting spectrum.

A similar, but more facile, carbonyl fluxionality is observed for $\left[\mathrm{Rh}_{10} \mathrm{As}(\mathrm{CO})_{22}\right]^{3-}$. In this case, the resonances in both the 25- and 90.56- $\mathrm{MHz}$ low-temperature $\left(-95^{\circ} \mathrm{C}\right)$ spectra are significantly broader than those found for $\left[R h_{10} P(C O)_{22}\right]^{3-}$ under the same conditions and, similarly, the fast-exchange carbonyl multiplet for $\left[\mathrm{Rh}_{10} \mathrm{As}(\mathrm{CO})_{22}\right]^{3-}$, observed at $+91{ }^{\circ} \mathrm{C}$ in $\mathrm{EtCN}$, is much better resolved than for $\left[\mathrm{Rh} \mathrm{h}_{10} \mathrm{P}(\mathrm{CO})_{22}\right]^{3-}$. The position of this multiplet [220.3 p.p.m., $J(\mathrm{Rh}-\mathrm{CO}) 9.3$ $\mathrm{Hz}$ ] is again close to the mean value of the carbonyl chemical shifts in the low-temperature spectrum and the pattern and multiplicity suggests that polyhedral rearrangement of the metal skeleton is occurring. This has been confirmed by collapsing the multiplet to a single line with low-power irradiation at a single rhodium resonance frequency $[\Xi$ $3.156922 \mathrm{MHz}, \delta\left(\mathrm{Rh}_{\mathrm{A}, \mathrm{B}}\right)-972$ p.p.m.], which is close to that expected from the value of $\delta(\mathrm{Rh})_{\text {mean }}-1075$ p.p.m. at $-95{ }^{\circ} \mathrm{C}$ after allowing for solvent and temperature effects (ca. +0.6 p.p.m. per ${ }^{\circ} \mathrm{C}$ ).

The same fluxional behaviour of both the carbonyl and metallic polyhedra also occurs in $\left[\mathrm{Rh}_{10} \mathrm{P}(\mathrm{CO})_{22}\right]^{3-}$. In this case, the behaviour of the metallic skeleton is best illustrated from variable-temperature ${ }^{31} \mathbf{P}$ n.m.r. measurements. At

$80{ }^{\circ} \mathrm{C}$ in acetone solution the ${ }^{31} \mathrm{P}$ n.m.r. spectrum is clearly different from that observed at $+76^{\circ} \mathrm{C}$ in sulpholane solution. At $-80 \mathrm{C}$, the resonance $\left[\delta\left({ }^{31} \mathrm{P}\right)+376.9\right.$ p.p.m. $]$ can be accurately simulated as a triplet, ${ }^{2} J\left(\mathrm{Rh}_{\mathrm{A}}-\mathrm{P}\right) 56 \mathrm{~Hz}$, of nonets, $1 J\left(\mathrm{Rh}_{\mathrm{B}}-\mathrm{P}\right) 21 \mathrm{~Hz}$, whereas at $+76{ }^{\circ} \mathrm{C}$ it is a well resolved undecet with $J\left(\mathrm{Rh}_{\mathrm{A}, \mathrm{B}}-\mathrm{P}\right)=31.7 \mathrm{~Hz}$ and $\delta\left({ }^{31} \mathrm{P}\right)+366$ p.p.m. This clearly shows that the metallic skeleton is static at low temperature but becomes fluxional at high temperature. The time-averaged value of $J\left(\mathrm{Rh}_{\mathrm{A}, \mathrm{B}}-\mathrm{P}\right)$ at $16^{\circ} \mathrm{C}$ is similar to the
Table 2. N.m.r. data for $\left[\mathrm{Rh} \mathrm{h}_{9} \mathrm{P}(\mathrm{CO})_{21}\right]^{2-}$ in $\left[{ }^{2} \mathrm{H}_{8}\right]$ tetrahydrofuran at low temperature $\left({ }^{13} \mathrm{C}\right.$ and ${ }^{13} \mathrm{C}-\left\{{ }^{103} \mathrm{Rh}\right\}$ measurements at $-99^{\circ} \mathrm{C}$, ${ }^{31} \mathrm{P}$ and ${ }^{13} \mathrm{C}-\left\{{ }^{31} \mathrm{P}\right\}$ measurements at $\left.-91{ }^{\circ} \mathrm{C}\right)$, together with the corresponding $\mathrm{Rh}-\mathrm{CO}$ bond lengths $(\AA)$ in parentheses

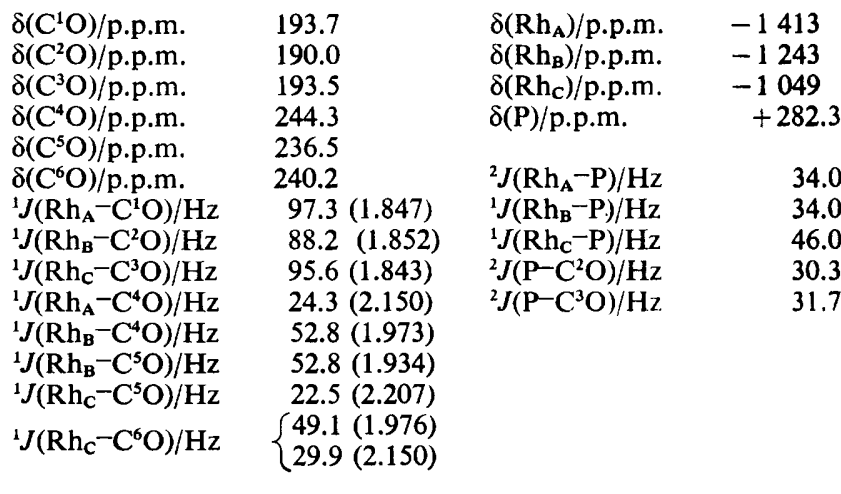

weighted mean of ${ }^{2} J\left(\mathrm{Rh}_{\mathrm{A}}-\mathrm{P}\right)$ and ${ }^{1} J\left(\mathrm{Rh}_{\mathrm{B}}-\mathrm{P}\right)$ obtained at $-80^{\circ} \mathrm{C}$. This suggests that both ${ }^{2} J\left(\mathrm{Rh}_{\mathrm{A}}-\mathrm{P}\right)$ and ${ }^{1} J\left(\mathrm{Rh}_{\mathrm{B}}-\mathrm{P}\right)$ at low temperature have the same sign, which is probably negative from previous studies. ${ }^{13}$ It is also worth noting that $\left|{ }^{2} J\left(\mathrm{Rh}_{\mathrm{A}}-\mathrm{P}\right)\right|>\left|{ }^{1} J\left(\mathrm{Rh}_{\mathrm{B}}-\mathrm{P}\right)\right|$. This is rather surprising, but is similar to the data on $J(\mathrm{Rh}-\mathrm{Pt})$ found for $\left[\mathrm{PtRh}_{5}(\mathrm{CO})_{15}\right]^{-},{ }^{14}$ and probably stems from the larger number of pathways available for transmission of spin-spin coupling in the twobond case.

$\left[\mathrm{Rh}_{9} \mathrm{E}(\mathrm{CO})_{21}\right]^{2-}(\mathrm{E}=\mathrm{P}$ or $\mathrm{As})$. - The variable-temperature ${ }^{13} \mathrm{C}$ n.m.r. spectra of $\left[\mathrm{Rh}{ }_{9} \mathrm{P}(\mathrm{CO})_{21}\right]^{2-}$ are shown in Figure $3(a)$. At $-90^{\circ} \mathrm{C}$, the spectrum is in accord with that expected from the solid-state structure and has been unambiguously assigned using a combination of ${ }^{13} \mathrm{C}-\left\{{ }^{103} \mathrm{Rh}\right\}$ and ${ }^{13} \mathrm{C}-\left\{{ }^{11} \mathrm{P}\right\}$ measurements, as described above for $\left[\mathrm{Rh}_{10} \mathrm{P}(\mathrm{CO})_{22}\right]^{3-}$. The resulting couplings are shown schematically in Figure $3(b)$ and the spectroscopic data are summarised in Table 2.

It should be noted that the resonance due to $\mathrm{C}^{1} \mathrm{O}$, which is coincident with $\mathrm{C}^{3} \mathrm{O}$ in the $25-\mathrm{MHz}$ spectrum, is clearly visible in the low-temperature $90.56-\mathrm{MHz}$ spectrum and, whereas ${ }^{2} J(\mathrm{P}-\mathrm{CO})$ was observed for both terminal and edge-bridging carbonyls in $\left[\mathrm{Rh}_{10} \mathrm{P}(\mathrm{CO})_{22}\right]^{3-}$, there is only coupling of the terminal carbonyls, $\mathrm{C}^{2} \mathrm{O}$ and $\mathrm{C}^{3} \mathrm{O}$, with the interstitial phosphorus in $\left[\mathrm{Rh}_{9} \mathrm{P}(\mathrm{CO})_{21}\right]^{2-}$.

As found for $\left[\mathrm{Rh}_{10} \mathrm{P}(\mathrm{CO})_{22}\right]^{3-}$, the edge-bridging carbonyls, $\mathrm{C}^{4} \mathrm{O}$, to the capping atom $\mathrm{Rh}_{\mathrm{A}}$ in $\left[\mathrm{Rh}_{9} \mathrm{P}(\mathrm{CO})_{21}\right]^{2-}$ are approximately trans to each other; this leads to $d\left(\mathrm{Rh}_{\mathrm{A}}-\mathrm{C}^{4} \mathrm{O}\right)>$ $d\left(\mathrm{Rh}_{\mathbf{B}}-\mathrm{C}^{4} \mathrm{O}\right)$, which is parallelled in the different values found for $J(\mathrm{Rh}-\mathrm{CO})$ (see Table 2$)$. The other edge-bridging carbonyls, $\mathrm{C}^{5} \mathrm{O}$ and $\mathrm{C}^{6} \mathrm{O}$, are also asymmetrically bridged because of a trans $-\mathrm{C}^{6} \mathrm{O}-\mathrm{Rh}_{\mathrm{C}}-\mathrm{C}^{5} \mathrm{O}$ configuration. This results in all $\mathrm{Rh}_{\mathrm{C}}-\mathrm{Rh}_{\mathrm{B}}$ edges being asymmetrically bridged with an alternation of long and short $\mathrm{Rh}_{\mathrm{C}}-\mathrm{C}^{6} \mathrm{O}$ bonds around the $\left[\mathrm{Rh}_{\mathrm{C}}\right]_{+}$square face; similarly, $d\left(\mathrm{Rh}_{\mathrm{C}}-\mathrm{C}^{5} \mathrm{O}\right)>d\left(\mathrm{Rh}_{\mathrm{B}}-\mathrm{C}^{5} \mathrm{O}\right)$. This asymmetric bridging found in the solid state seems to be retained in solution as exemplified by the different values found for ${ }^{1} J\left(\mathrm{Rh}^{-\mathrm{CO}}\right)$ with short rhodium-carbonyl bonds giving rise to high values of ${ }^{1} J(\mathrm{Rh}-\mathrm{CO})$ (Table 2$)$.

Variable-temperature ${ }^{13} \mathrm{C}$ n.m.r. measurements on $\left[R h_{9} P\right.$ $\left.(\mathrm{CO})_{21}\right]^{2-}$ show the simultaneous broadening of all the carbonyl resonances until a broad resonance is obtained at room temperature; this broad resonance collapses to a sharp doublet $[J(\mathrm{P}-\mathrm{CO}) 12.2 \mathrm{~Hz}]$ on irradiation at a single rhodium resonance frequency $[\Xi 3.156347 \mathrm{MHz} ; \delta(\mathrm{Rh})=-1161$ p.p.m.] which is close to $\delta(\mathrm{Rh})_{\text {mean }} \quad 1176$ p.p.m. at -90 "C. This is in agreement with both the carbonyl and metal skele- 
(a)

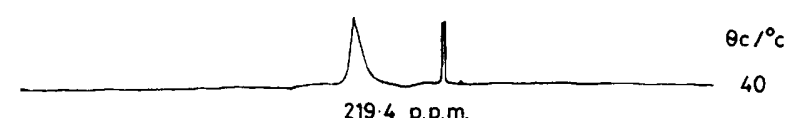

219.4 p.p.m.

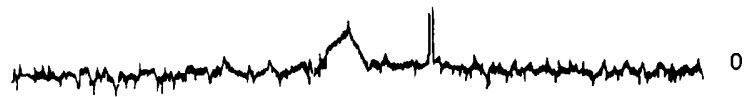

$-25$
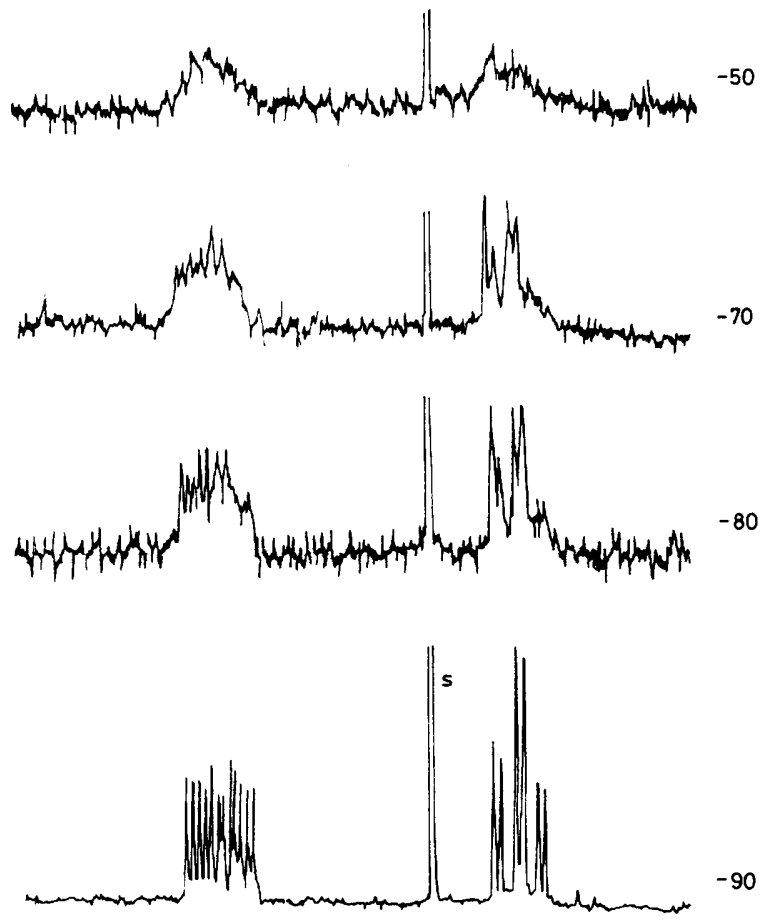

(b)

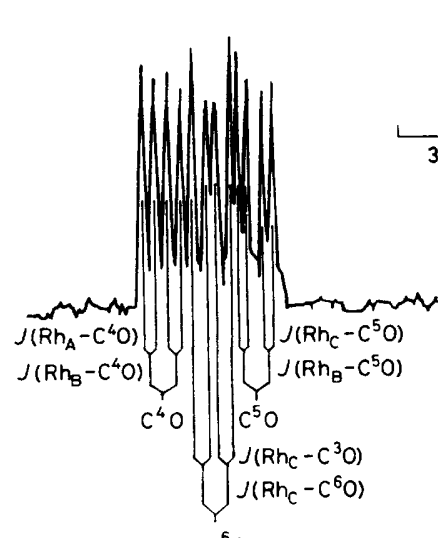

$c^{6} \mathrm{O}$

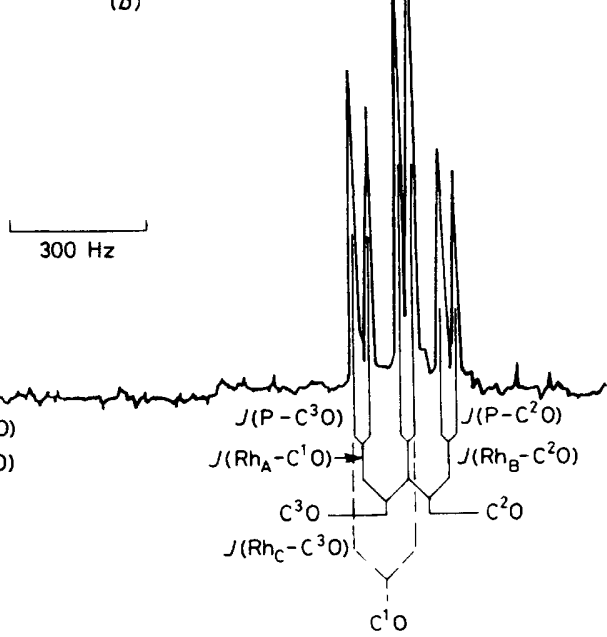

Figure 3. (a) Variable-temperature $25-\mathrm{MHz}{ }^{13} \mathrm{C}$ n.m.r. spectra of $\left[\mathrm{Cs}\left\{\mathrm{Me}\left(\mathrm{OCH}{ }_{2} \mathrm{CH}_{2}\right)_{4} \mathrm{OMe}\right\}_{2}\left[\mathrm{Rh}{ }_{4} \mathrm{P}(\mathrm{CO})_{21}\right] \text { in }(\mathrm{CD})_{3}\right)_{2} \mathrm{CO} ;($ b) expansion of spectrum at $-90^{\circ} \mathrm{C}$ together with assignments (see Figure 1). $\mathrm{S}=$ solvent 
(a)

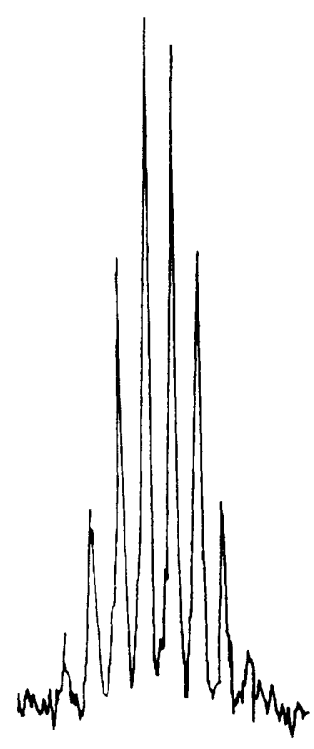

(b)

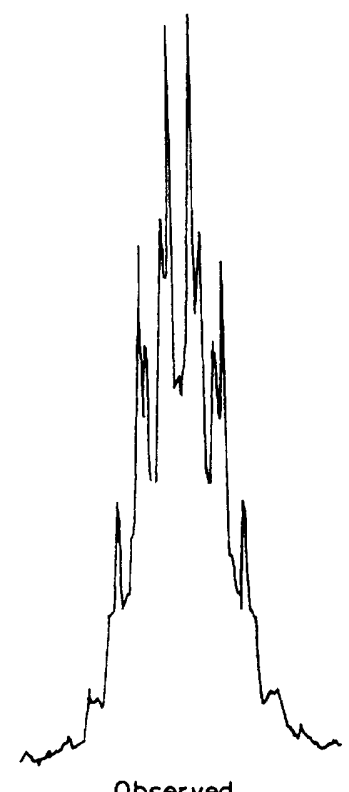

Observed
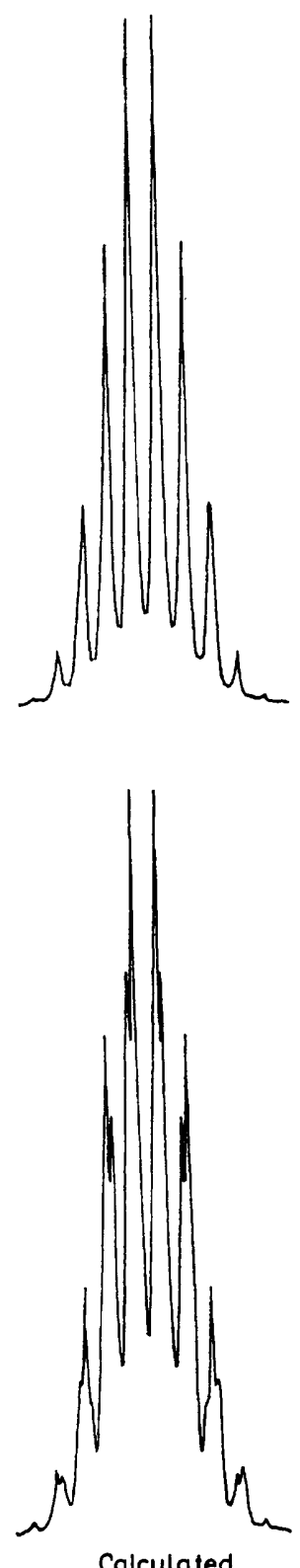

Calculated

Figure 4. Observed and simulated ${ }^{31} \mathrm{P}$ n.m.r. spectra of [Cs $\{\mathrm{Me}-$ $\left.\left.\left(\mathrm{OCH}_{2} \mathrm{CH}_{2}\right)_{4} \mathrm{OMe}\right\}\right]_{2}\left[\mathrm{Rh}_{9} \mathrm{P}(\mathrm{CO})_{21}\right]$ in $\left(\mathrm{CD}_{3}\right)_{2} \mathrm{CO}$ at $(a)+25{ }^{\circ} \mathrm{C}$ $\left[J\left(\mathrm{Rh}_{\mathrm{A}}-\mathrm{P}\right)=J\left(\mathrm{Rh}_{\mathrm{B}}-\mathrm{P}\right)=J\left(\mathrm{Rh}_{\mathrm{C}}-\mathrm{P}\right)=38.4 \mathrm{~Hz}\right]$ and $(b)-80^{\circ} \mathrm{C}$ $\left[J\left(\mathrm{Rh}_{\mathrm{A}}-\mathrm{P}\right)=J\left(\mathrm{Rh}_{\mathrm{B}}-\mathrm{P}\right)=34.0, J\left(\mathrm{Rh}_{\mathrm{C}}-\mathrm{P}\right)=46.0 \mathrm{~Hz}\right]$

tons being fluxional, as suggested earlier from rhodium n.m.r. measurements, ${ }^{4}$ and is further confirmed by variable-temperature ${ }^{31} \mathbf{P}$ n.m.r. measurements.

The low-temperature ${ }^{31} \mathrm{P}$ n.m.r. spectrum of $\left[\mathrm{Rh}{ }_{9} \mathrm{P}(\mathrm{CO})_{21}\right]^{2-}$ is shown in Figure $4(b)$ and may be simulated as a triplet, ${ }^{2} J\left(\mathrm{Rh}_{\mathrm{A}}-\mathrm{P}\right)=34 \mathrm{~Hz}$, of quintets, ${ }^{1} J\left(\mathrm{Rh}_{\mathrm{B}}-\mathrm{P}\right)=34 \mathrm{~Hz}$, of quintets, ${ }^{1} J\left(\mathrm{Rh}_{\mathrm{C}}-\mathrm{P}\right)=46 \mathrm{~Hz}$. These values differ from those previously reported but reinspection of the rhodium spectrum shows that the apical rhodium-phosphorus coupling $\left[{ }^{2} J\right.$ $\left(\mathrm{Rh}_{\mathrm{A}}-\mathrm{P}\right)$ in Figure 2 of ref. 4] must be revised. It should also be noted that, because of our ${ }^{13} \mathrm{C}-\left\{{ }^{103} \mathrm{Rh}\right\}$ measurements, the direct ${ }^{103} \mathrm{Rh}$ n.m.r. assignments of the rhodium resonances previously attributed to the two sets of inequivalent squareantiprismatic rhodium atoms, $\mathrm{Rh}_{\mathrm{B}}$ and $\mathrm{Rh}_{\mathrm{C}}$ (Figure 1 ), ${ }^{4}$ must now be reversed. At room temperature, the ${ }^{31} \mathbf{P}$ n.m.r. spec-

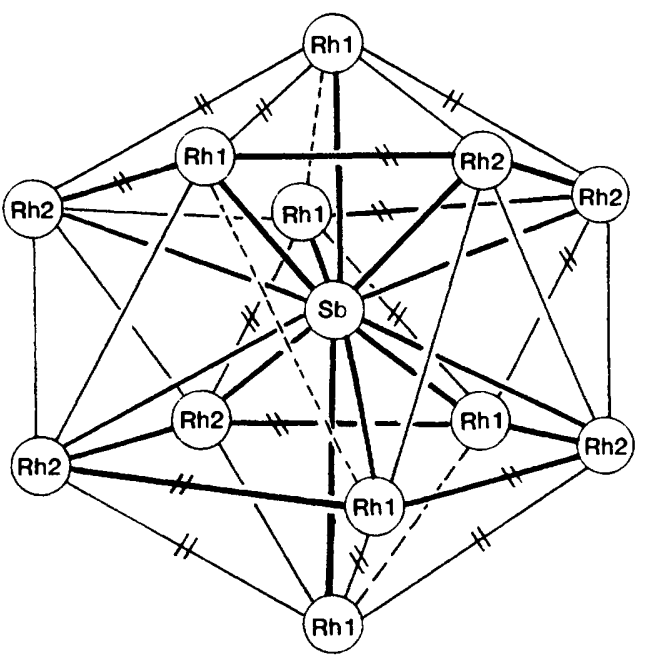

Figure 5. Schematic representation of the structure of $\left[\mathrm{Rh}_{12} \mathrm{Sb}\right.$ $\left.(\mathrm{CO})_{27}\right]^{3-}$. Each rhodium is bonded to one terminal carbonyl, which has been omitted for the sake of clarity, and bridging carbonyls are indicated by the symbol \#

trum [Figure 4(a)] becomes a symmetrical decet due to equal couplings to all nine rhodium atoms $\left[J\left(\mathrm{Rh}_{\mathrm{A}, \mathrm{B}, \mathrm{C}}-\mathrm{P}\right)=38.5\right.$ $\mathrm{Hz}$ ] caused by randomisation of the rhodium polyhedron about the interstitial phosphorus. The time-averaged value of $J\left(\mathrm{Rh}_{\mathrm{A}, \mathrm{B}, \mathrm{C}}-\mathrm{P}\right)$ is close to the weighted mean of the lowtemperature rhodium-phosphorus couplings and again implies that the rhodium-phosphorus spin-spin couplings observed at low temperature all have the same sign.

$\left[\mathrm{Rh}_{12} \mathrm{Sb}(\mathrm{CO})_{27}\right]^{3-}$. - The structure of this cluster, which is represented schematically in Figure 5, consists of a distorted icosahedral arrangement of rhodium atoms; each rhodium has one terminal carbonyl and the remaining 15 edge-bridging carbonyls are distributed as shown in the Figure. ${ }^{5}$ It has not been possible to obtain the low-temperature limiting spectrum since the $90.56-\mathrm{MHz}{ }^{13} \mathrm{C}$ n.m.r. spectrum at $-97.5^{\circ} \mathrm{C}$ consists of only a broad resonance $[\delta(C O) 230.6$ p.p.m.] due to the edge-bridging carbonyls and a broad doublet $[\delta(\mathrm{CO})$ 198.6 p.p.m., $J(\mathrm{Rh}-\mathrm{CO}) 100.7 \mathrm{~Hz}$ ] due to the terminal carbonyls. At room temperature, however, both the metallic and carbonyl skeletons become fluxional since 11 lines of the expected 13-line symmetrical multiplet are observed $[\delta(\mathrm{CO})$ 216.6 p.p.m., $J(\mathrm{Rh}-\mathrm{CO}) 7.3 \mathrm{~Hz}]$ in the $25-\mathrm{MHz}{ }^{13} \mathrm{C}$ n.m.r. spectrum and low-power rhodium decoupling at a single frequency $[\Xi 3.157672 \mathrm{MHz}, \delta(\mathrm{Rh})-742$ p.p.m.] collapses this multiplet to a singlet.

\section{Discussion}

Comparison of the variable-temperature ${ }^{13} \mathrm{C}$ n.m.r. spectra of $\left[\mathrm{Rh}_{9} \mathrm{E}(\mathrm{CO})_{21}\right]^{2-}$ and $\left[\mathrm{Rh}_{10} \mathrm{E}(\mathrm{CO})_{22}\right]^{3-}$ shows that, in both cases, carbonyl fluxionality is more facile when $\mathrm{E}=\mathrm{As}$ than when $E=P$. As both carbonyl and metal polyhedral rearrangements in the above compounds appear to be interconnected, it seems probable that this stems from an expansion of the metal skeleton which is necessary in order to accommodate the larger interstitial arsenic atom $\left\{\right.$ for $\left[R h_{10} E\right.$ $\left.(\mathrm{CO})_{22}\right]^{3-} d\left(\mathrm{Rh}_{\mathrm{A}}-\mathrm{Rh}_{\mathrm{B}}\right)=2.841$ and $2.869 \AA$ and $d\left(\mathrm{Rh}_{\mathrm{B}}-\mathrm{Rh}_{\mathrm{B}}\right)$ $=2.859$ and $2.895 \AA$ for $\mathrm{E}=\mathbf{P}$ and As respectively\}. This would be expected to result in a lower activation energy for randomisation of metal atoms in the less strongly bound arsenido-species and this would, in turn, lower the activation energy for carbonyl migration. 
(a)
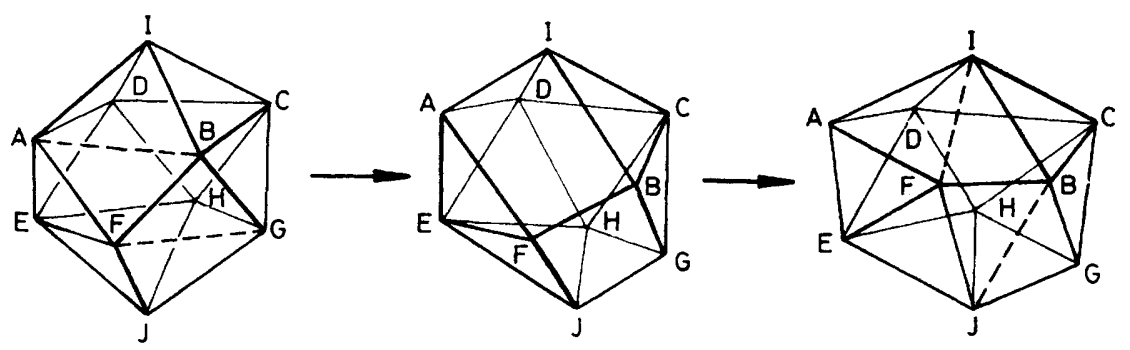

(b)

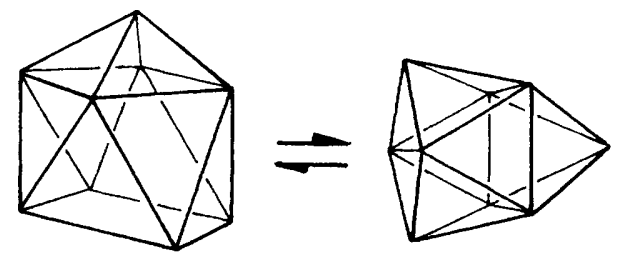

Capped square

Symmetrically tricapped

antiprism $C_{4 v}$

(c)

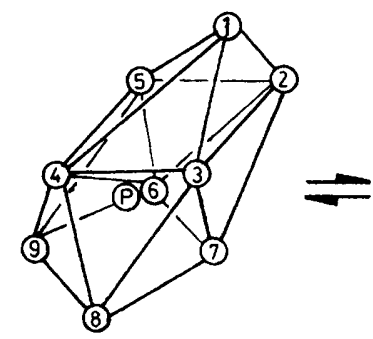

trigonal prism $D_{3 h}$

(d)
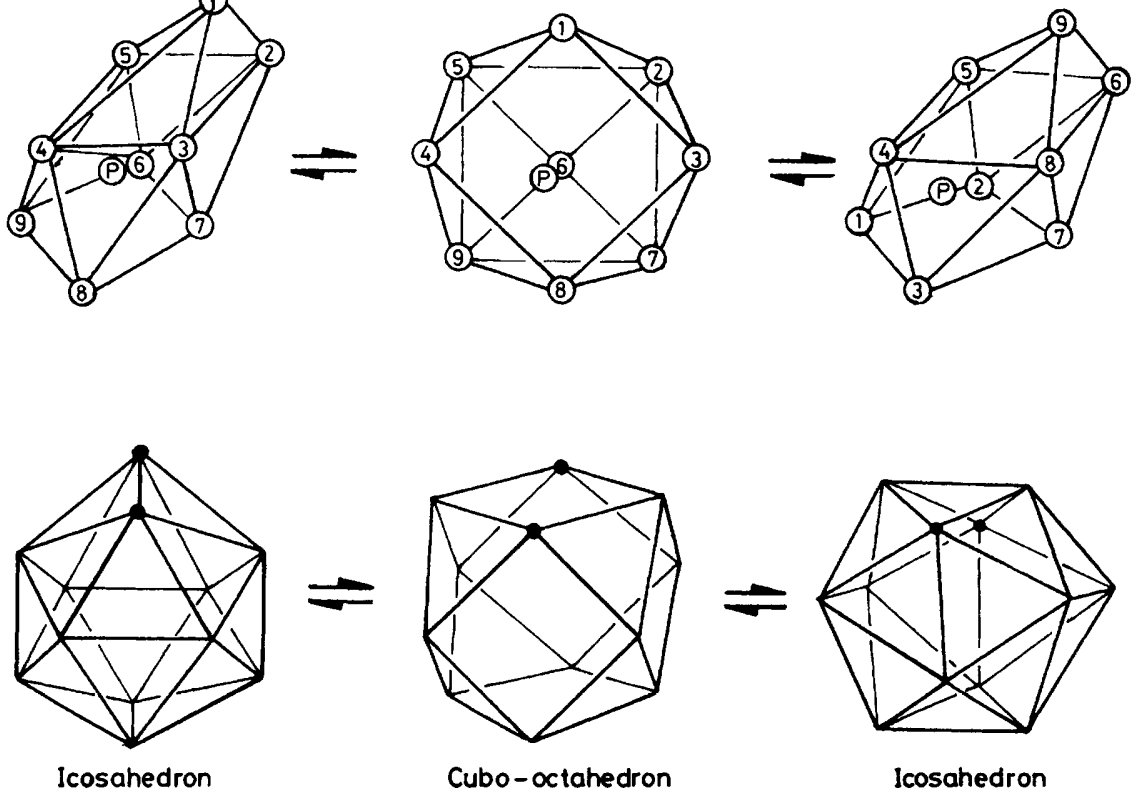

Cubo-octahedron

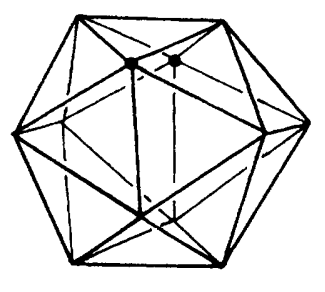

Icosahedron

Figure 6. Schematic representation of the possible mechanisms for metal skeletal rearrangements of $(a)\left[R h_{10} E(C O)_{22}\right]^{3-},(b),(c)$ $\left[\mathrm{Rh}{ }_{9} \mathrm{E}(\mathrm{CO})_{21}\right]^{2-}$, and $(d)\left[\mathrm{Rh}_{12} \mathrm{Sb}(\mathrm{CO})_{27}\right]^{3-}$

Although it is impossible to define exactly the migratory pathways of the metallic skeletons, it seems probable that they are related to similar rearrangements found for boron polyhedra in boron hydrides. Thus, the fluxionality of the boron cage in $\left[\mathrm{B}_{10} \mathrm{H}_{10}\right]^{2-}$ has been proposed ${ }^{15}$ to occur by the concerted process shown in Figure $6(a)$ and a similar rearrangement could be involved in the $\mathrm{Rh}_{10}$ clusters. Similarly, rearrangement of the $C_{4 v} \mathrm{Rh}_{9}$ capped-square-antiprismatic skeleton via a $D_{3 h}$ tricapped trigonal prism [Figure $6(b)$ ] as proposed for boranes and other nine-atom clusters ${ }^{16,17}$ could account for randomisation of the $R h_{9}$ polyhedron, although it is also feasible that a concerted rhodium-rhodium bondbreaking and -making process [Figure $6(c)$ ] could be involved.

For $\left[\mathrm{Rh}_{12} \mathrm{Sb}(\mathrm{CO})_{27}\right]^{3-}$ the presence of three long rhodiumrhodium bonds probably facilitates metal polyhedral rearrangement, which is perhaps similar to that reported for 1,2-dicarba-closo-dodecaborane, 1,2- $\mathrm{C}_{2} \mathrm{~B}_{10} \mathrm{H}_{12}$ [Figure $\left.6(d)\right]$, ${ }^{18}$ as previously suggested on the basis of the solid-state structure. $^{5}$

Finally, it should be noted that for rhodium carbonyl clusters containing interstitial metal atoms, $\left[\mathrm{Rh}_{13}(\mathrm{CO})_{24^{-}}\right.$ $\left.\mathrm{H}_{5-n}\right]^{n-}(n=1-4)^{19}$ and $\left[\mathrm{Rh}_{14}(\mathrm{CO})_{24} \mathrm{H}_{4-n}\right]^{n-}(n=3$ or 4$),{ }^{12}$ we have no evidence for rearrangement of the metallic skeleton. In these cases, there is probably a more compact rigid metallic skeleton than is possible for clusters containing interstitial heteroatoms.

\section{Acknowledgements}

We appreciate financial support from S.E.R.C. and the award of a fellowship (to L. S. and R. D. P.). We are also grateful to Union Carbide Corporation for permission to publish this work and to Dr. G. L. O'Connor for his continuous encouragement of basic research. We also thank Mr. T. Dickens for simulating the ${ }^{31} \mathbf{P}$ n.m.r. spectra.

\section{References}

1 J. L. Vidal, W. E. Walker, R. L. Pruett, and R. C. Schoening, Inorg. Chem., 1979, 18, 129.

2 J. L. Vidal, Inorg. Chem., 1981, 20, 241. 
3 J. L. Vidal, W. E. Walker, and R. C. Schoening, Inorg. Chem., $1981,20,238$.

4 O. A. Gansow, D. S. Gill, F. J. Bennis, J. R. Hutchinson, J. L. Vidal, and R. C. Schoening, J. Am. Chem. Soc., 1980, 102, 2449. 5 J. L. Vidal and J. H. Troup, J. Organomet. Chem., 1982, 213, 351. 6 J. L. Vidal, W. E. Walker, R. L. Pruett, and R. C. Schoening, Inorg. Chem., 1979, 18, 1821.

7 B. T. Heaton, L. Strona, S. Martinengo, D. Strumolo, R. J. Goodfellow, and I. H. Sadler, J. Chem. Soc., Dalton Trans., 1982, 1499.

8 C. Brown, B. T. Heaton, L. Longhetti, W. T. Povey, and D. O. Smith, J. Organomet. Chem., 1980, 192, 93.

9 B. T. Heaton, L. Longhetti, L. Garlaschelli, and U. Sartorelli, J. Organomet. Chem., 1980, 192, 431.

10 L. Garlaschelli, A. Fumagalli, S. Martinengo, B. T. Heaton, D. O. Smith, and L. Strona, J. Chem. Soc., Dalton Trans., 1982, 2265.

11 R. G. Kidd and R. J. Goodfellow, in ' N.M.R. and the Periodic Table,' eds. R. K. Harris and B. E. Mann, Academic Press, London, 1978, 244.
12 B. T. Heaton, C. Brown, D. O. Smith, L. Strona, R. J. Goodfellow, P. Chini, and S. Martinengo, J. Am. Chem. Soc., 1980, 102,6175 .

13 E. M. Hyde, J. D. Kennedy, B. L. Shaw, and W. McFarlane, J. Chem. Soc., Dalton Trans., 1977, 1571.

14 A. Fumagalli, S. Martinengo, P. Chini, A. Albinati, S. Bruckner, and B. T. Heaton, J. Chem. Soc., Chem. Commun., 1978, 195.

15 E. L. Muetterties, 'Boron Hydride Chemistry,' Academic Press, New York, 1975.

16 L. J. Guggenburger and E. L. Muetterties, J. Am. Chem. Soc., $1976,98,7221$.

17 R. W. Rudolph, W. L. Wilson, F. Parker, R. C. Taylor, and D. C. Young, J. Am. Chem. Soc., 1978, 100, 4629.

18 W. N. Lipscomb, Science, 1966, 153, 373.

19 S. Martinengo, B. T. Heaton, R. J. Goodfellow, and P. Chini, J. Chem. Soc., Chem. Commun., 1977, 39.

Received 12th November 1982; Paper 2/1907 